\title{
REPRODUCTION BY JUNE SUCKER IN A REFUGE POPULATION: SUCCESSFUL SPAWNING IN A LAKE HABITAT
}

\author{
Eric J. Billman ${ }^{1,2}$
}

\begin{abstract}
The June sucker (Chasmistes liorus) is an endangered lake sucker endemic to Utah Lake, Utah. As part of recovery actions, June suckers were introduced into Red Butte Reservoir, Utah, as a wild grow-out site. Since their introduction, June suckers have successfully reproduced in Red Butte Reservoir, producing a large population in this refuge. I used passive egg collectors (egg traps and nets) and observational surveys to determine the location of spawning sites within the reservoir, and larval light trapping to determine successful recruitment (i.e., egg survival through larval swim-up) at these sites. Eggs were collected between 18 June and 15 July at 2 general sites along or near the reservoir's dam, although spawning was only observed at 1 of these sites. Suckers were not observed at, and eggs were not collected in or around, the mouth of Red Butte Creek as expected. At the site where spawning was observed, suckers were spawning over gravel substrates (mean diameter $=32 \mathrm{~mm}$ ) at depths of $0.5-1.75 \mathrm{~m}$. At the other site, suckers were spawning over silt/clay substrates (mean diameter $<1 \mathrm{~mm}$ ) at depths of $1.1-4.75 \mathrm{~m}$. Larval suckers were first captured along the dam where spawning was observed and eggs were captured, demonstrating that successful recruitment occurred at this spawning site. Larval suckers were never captured at the mouth of Red Butte Creek, confirming egg collecting data and observations that suckers did not utilize the stream for spawning. This June sucker refuge population is supported by lacustrine spawning, an important finding for management and recovery of this species.
\end{abstract}

Key words: Chasmistes liorus, Red Butte Reservoir, egg trap, egg net, Utah Lake.

A unique group of catostomids in western North America are obligatory lake dwellers: the 3 extant species of the genus Chasmistes (the shortnose sucker Chasmistes brevirostris, the cui-ui sucker Chasmistes cujus, and the June sucker Chasmistes liorus) and the single species of the genus Deltistes (the Lost River sucker Deltistes luxatus). These lake suckers, as they are collectively named (Scoppettone and Vinyard 1991), share similar life histories in that they are long lived (30-40 years; Scoppettone 1988, Belk 1998) and highly fecund (iteroparous with 20,000 to $\geq 200,000$ eggs per female per year; Scoppettone and Vinyard 1991). These characteristics enable lake suckers to persist in the dynamic and variable desert lakes where they are found. However, the 4 extant species have been federally listed as endangered largely due to anthropogenic disturbances to their ecosystems (Scoppettone and Vinyard 1991).

All species of lake suckers have been classified as obligatory stream spawners, meaning that adults spawn in tributaries of their lacustrine habitat, typically during spring runoff (Scoppettone and Vinyard 1991). However, many of these species have proven to be facul- tative spawners, as reproduction has been observed in lacustrine habitats where adult suckers apparently select for optimal substrate and temperature in the absence of flowing water (Koch 1973, Scoppettone et al. 2000, National Research Council 2004). Similarly, riverine suckers (e.g., razorback sucker Xyrauchen texanus) have been documented to be facultative spawners, utilizing lacustrine spawning sites when rivers are converted to reservoirs by large dam projects (Bozek et al. 1991). Of the lake suckers, the June sucker appears to be the exception to the facultative spawning in lake suckers. Endemic to Utah Lake, the June sucker has been observed spawning during May and June in only tributaries to Utah Lake, most densely in the lower reaches of the Provo River (Sigler and Sigler 1987, Modde and Muirhead 1994, U.S. Fish and Wildlife Service 1999, Whitney and Belk 2000).

After severe population declines to fewer than 1000 adults, the June sucker was federally classified as endangered with critical habitat, effective 31 March 1986 (USOFR 1986). The reasons for the listing included habitat loss and lack of recruitment to the adult population due to predation by nonnative fish species and 
lack of suitable rearing habitat (Whitney and Belk 2000, Belk et al. 2001). In 1992, Red Butte Reservoir, Utah, was stocked with approximately 3215 June suckers representing 3 cohorts from streamside artificial spawning efforts for species conservation (Billman 2005, Andersen et al. 2007). At the time, the reservoir and its drainage were managed as a Research Natural Area, which provided security and minimized threats to the new population (Ehleringer et al. 1992). June suckers were not expected to reproduce in the reservoir, as access to the only tributary was blocked by a waterfall; thus, the reservoir was originally intended to serve as a natural grow-out site to raise these fish prior to stocking into Utah Lake to augment the wild population (Buelow et al. 2006). However, beginning 3 years after introduction, suckers successfully reproduced in the reservoir, establishing a population that exceeded 13,000 age-1 and older suckers by 2004 (Billman and Crowl 2007). This elevated the importance of Red Butte Reservoir for recovery purposes, as recruitment failure in their native habitat was the primary reason for their listing as an endangered species.

Establishment of this refuge population was not only encouraging for conservation of the June sucker but it has also provided an opportunity to study this rare fish in a seminatural environment without nonnative fishes. Of particular interest are the location and habitat characteristics of the spawning sites used by June suckers in this reservoir. As already indicated, a substantial June sucker population has been established in the reservoir apparently from reproduction within the reservoir, not Red Butte Creek, suggesting that June suckers are also facultative spawners (Billman and Crowl 2007). This paper details my efforts to (1) identify and characterize spawning sites used by June sucker in Red Butte Reservoir and (2) determine if successful recruitment occurred at these sites.

\section{Methods}

\section{Study Site}

Red Butte Reservoir is located in a small, narrow canyon on the west slopes of the Wasatch Mountains east of Salt Lake City, Utah. During this study, the reservoir had a surface elevation of $1636 \mathrm{~m}$, a surface area of $4.1 \mathrm{ha}$, and mean and maximum depths of 7.8 $\mathrm{m}$ and $12.2 \mathrm{~m}$, respectively. Also, at this elevation the water level was $2.6 \mathrm{~m}$ below the maximum capacity of the reservoir; thus, water was only released from the reservoir through a hypolimnion release rather than over the spillway. The reservoir has a single tributary, Red Butte Creek, a small 3rd-order stream with an average monthly discharge of $0.133 \mathrm{~m}^{3} \cdot \mathrm{s}^{-1}$ at its mouth in the reservoir (Ehleringer et al. 1992). Red Butte Creek exhibits an annual flow pattern characteristic of the region: high spring flows driven by snowmelt (maximum instantaneous discharge $\left.0.623 \mathrm{~m}^{3} \cdot \mathrm{s}^{-1}\right)$ followed by reduced flows derived from groundwater throughout the remainder of the year (minimum instantaneous discharge of $0.020 \mathrm{~m}^{3}$. $\mathrm{s}^{-1}$ ). Bonneville cutthroat trout Oncorhynchus clarki is the only other fish species present in the reservoir.

\section{Spawning Site Surveys}

In spring 2003, I assessed egg deposition using passive egg collectors at potential spawning sites. I assumed that June suckers would spawn over gravel or cobble substrates (U.S. Fish and Wildlife Service 1999) near the mouth of or in Red Butte Creek, or along shores with gradual slopes in depths not exceeding $6 \mathrm{~m}$. The egg collection gear consisted of $25 \mathrm{egg}$ nets (Horns et al. 1989) and 52 egg traps (Marsden et al. 1991). Each net or trap was attached individually to a small cement anchor and a nylon rope, which had a buoy at the opposite end. Traps and nets were deployed on 12 May and checked weekly for the presence of eggs until the end of July. June sucker eggs were easily identified because they are much smaller than the eggs of cutthroat trout, the only other fish species in the reservoir (Sigler and Sigler 1996, Crisp 2000). The following parameters were measured weekly at the site of each egg trap and net: depth (m), measured with a graduated rope with a weight attached to one end; and temperature $(\mathrm{C})$ and dissolved oxygen $\left(\mathrm{mg} \cdot \mathrm{L}^{-1}\right)$, both measured with a YSI 55 dissolved oxygen meter (YSI Incorporated, Yellow Springs, OH). The substrate at spawning sites was qualitatively categorized at each site in fall 2003 when a reduction in water level in the reservoir exposed sites where eggs were collected and spawning was observed.

Weekly observational surveys were conducted from boat and onshore around the shoreline of the reservoir and near the mouth 


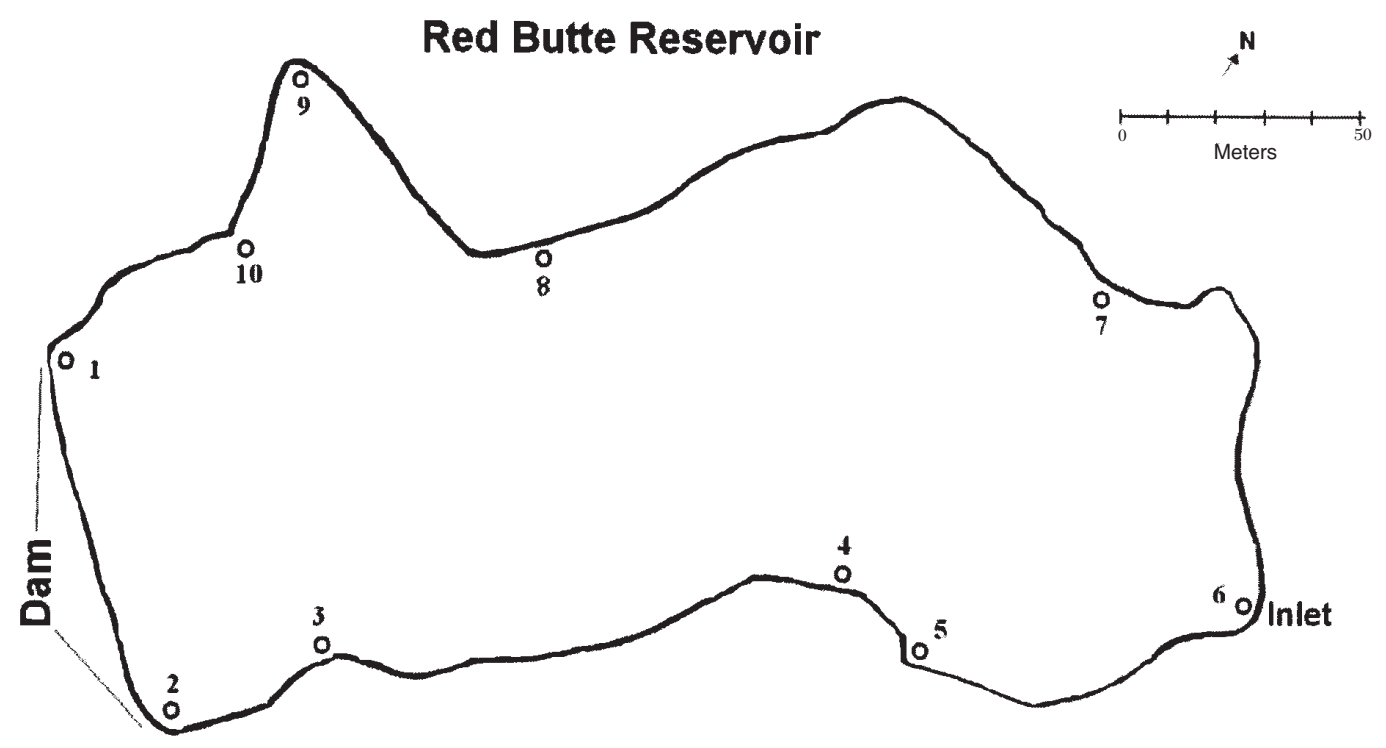

Fig. 1. Sites for larval light trapping and spotlighting in Red Butte Reservoir, Utah, 2002 and 2003.

of Red Butte Creek in attempts to observe spawning behavior. Although spawning has been reported to occur at night, I still expected to see suckers staging at or near potential spawning sites during the day (U.S. Fish and Wildlife Service 1999). Visibility was limited in the reservoir during this time (secchi disk depth $=1.0 \mathrm{~m}$; Billman 2005). In the mouth of Red Butte Creek, where visibility was higher, I snorkeled during daylight hours to determine if suckers were congregating or spawning.

\section{Larval Light Trapping}

To assess recruitment, I conducted larval light trap and spotlighting surveys in 2002 and 2003. I assumed that the presence of larval suckers that had reached the swim-up stage represented successful recruitment. Between 19 June and 18 July 2002, I used 6 Quatrefoil light traps (Southern Concepts, Birmingham, AL) on 7 nights (Floyd et al. 1984). I selected 10 fixed sites on the perimeter of the reservoir, and on each night of sampling, the light traps were set at 6 of the 10 fixed sites (Fig. 1). Light traps were floated from $1.2-\mathrm{m}$ metal rods driven into bottom substrates in water depths ranging from 0.3 to $1.0 \mathrm{~m}$. Light traps were set at sunset and retrieved just prior to sunrise. In 2003, 3-6 light traps were set (using the methods described above) once per week from 14 May to 24 June. Additionally, I assessed presence or absence of larvae once per week at the same
10 sites using spotlighting surveys conducted at night between 22:00 and 01:00. I did this by shining a spotlight from a canoe into the water for 5 minutes at each site and recording whether or not I observed larval suckers. Sampling in 2003 was not continued after 24 June because larval suckers had dispersed throughout the reservoir excluding the mouth of Red Butte Creek, and their locations were no longer indicative of original spawning sites.

\section{RESUlts}

\section{Spawning Site Surveys}

A total of 36 June sucker eggs were captured in 3 egg traps and 5 egg nets in 2 general locations: (1) along the south corner of the dam, and (2) in a cove on the north shore of the reservoir (Fig. 2). At the site along the south corner of the dam, 22 eggs were captured from 18 June through 15 July. Suckers were spawning over predominately gravel substrates at depths between $0.5 \mathrm{~m}$ and $1.75 \mathrm{~m}$. During the time period when eggs were collected, water temperatures at this site ranged between 16.0 and $20.5{ }^{\circ} \mathrm{C}$, and dissolved oxygen concentration ranged from 7.73 to $8.33 \mathrm{mg} \cdot \mathrm{L}^{-1}$. In the cove on the north shore of the reservoir, 14 eggs were captured on 24 June and 1 July. Eggs were captured at depths of 1.1-4.75 m over clay and silt substrates. At this site, water 


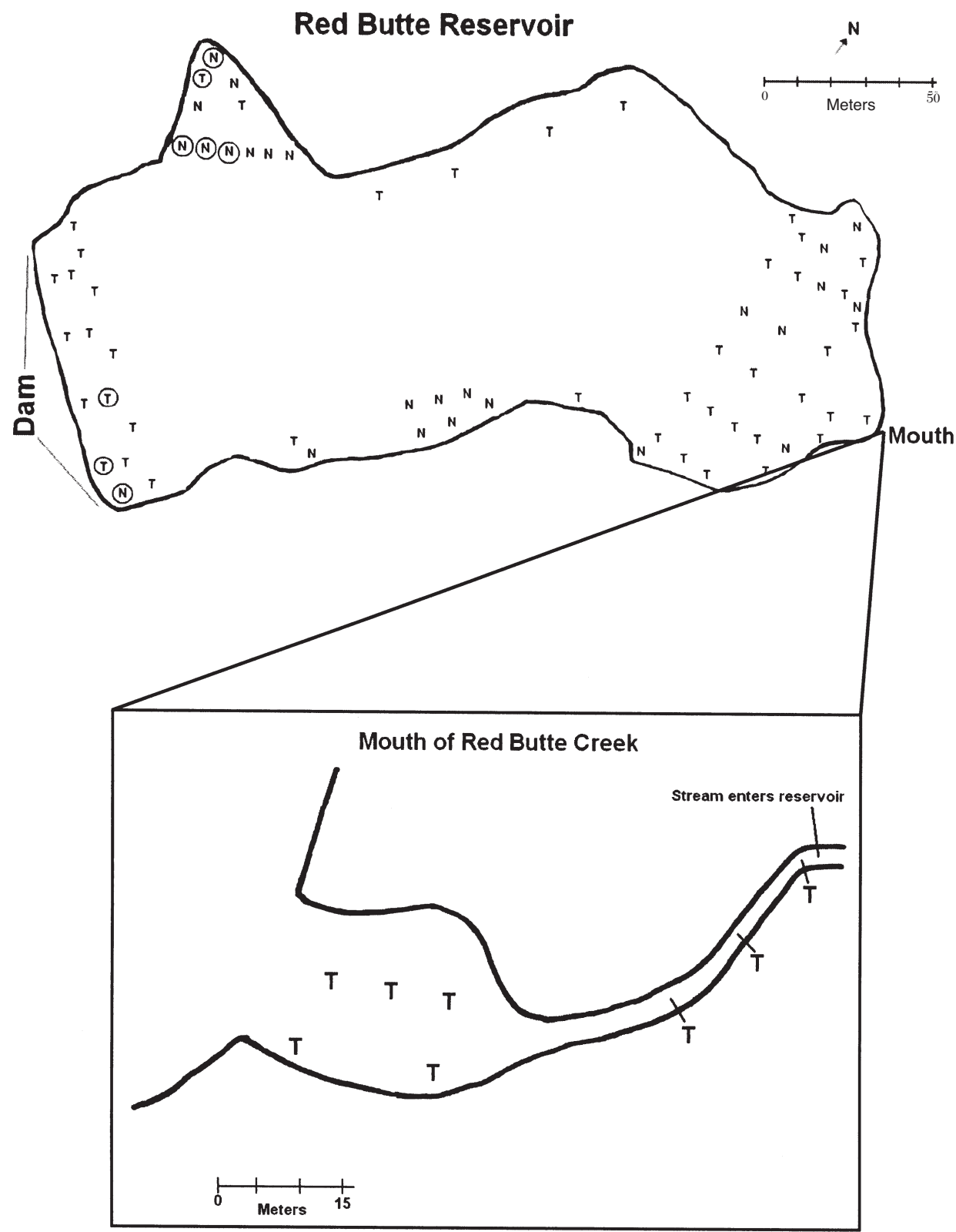

Fig. 2. Locations of egg traps $(\mathrm{T})$ and egg nets $(\mathrm{N})$ used to locate spawning sites of June sucker in Red Butte Reservoir, Utah. Egg traps or nets where eggs were collected are circled. A total of 36 eggs were collected, 22 eggs along the dam and 14 eggs in the cove on the north shore.

temperature ranged between 15.7 and $17.9^{\circ} \mathrm{C}$, and dissolved oxygen ranged from 7.63 to 8.63 $\mathrm{mg} \cdot \mathrm{L}^{-1}$.

Spawning behavior was observed only at the site along the south corner of the dam. From 10 June through 8 July, groups of 2 or more suckers could be seen swimming in shallow water $(<1 \mathrm{~m}$ deep) along the south corner of the dam. Most observations were made during daylight hours, although spawning suckers were observed at this site during nighttime larval spotlighting surveys. Spawning behavior, which was similar to that of cui-ui suckers (Koch 1973, Scoppettone et al. 1983), was 
recorded with an underwater video camera (video footage available from: http://www .junesuckerrecovery.org/abou-spaw.html). Generally, a single female (females distinguished from males by their uniform color) was flanked by 2 or more males (identified by a dark lateral band running from head to tail); spawning occurred when all the fish in the cluster vibrated vigorously for a few seconds before swimming away quickly (Shirley 1983). Clusters appeared as a swarming mass of suckers from shore observations, possibly from males aggressively seeking positions most adjacent to spawning females. Spawning behavior was not observed in the cove on the north shore of the reservoir. Similarly, no suckers were observed in the stream or at or near the mouth of the stream.

\section{Larval Light Trapping}

June suckers had successful larval recruitment in both 2002 and 2003. In 2002 larval June suckers were captured on each night of trapping, with a total of 17 suckers captured. Larval June suckers $(n=12 ; 11-13 \mathrm{~mm}$ TL) were captured only at sites 1 and 2 along the dam from 19 June until 11 July, when larger young of year $(n=5 ; 22-33 \mathrm{~mm}$ TL) were captured at sites 4 and 7 on the south and east ends of the reservoir. In 2003 larval June suckers were first observed on 17 June. In spotlighting surveys, I observed hundreds of larval suckers at site 2 on the south corner of the dam on 17 June, 1 week after I first observed spawning at this site; I did not observe larval suckers while spotlighting at other sites. However, 1 larval sucker was captured in a light trap at site 9 in the cove on the north side of the reservoir. The following week (24 June), I observed larval suckers during spotlighting surveys at all sites around the reservoir except site 6 at the mouth of Red Butte Creek. Larval trapping was discontinued at this time because the distribution of larvae would no longer be indicative of original spawning sites.

\section{Discussion}

From this study, I found evidence that June suckers were successfully spawning in Red Butte Reservoir, demonstrating that they are facultative spawners rather than obligate stream spawners. I found no evidence that spawning occurred in or was associated with the flowing water from the stream. In fact, spawning in this refuge population occurred at the opposite end of the reservoir from the mouth of the stream. At the site where eggs were captured and spawning was observed, June suckers were spawning over substrates similar to those used in the Provo River; depth of spawning was greater in Red Butte Reservoir, but this difference could be due simply to incidental depth of appropriate substrates (U.S. Fish and Wildlife Service 1999, Whitney and Belk 2000). Spawning occurred in June, as expected, but the timing was later than when June suckers spawn in Provo River, likely due to colder temperatures in the reservoir, as spawning is temperature driven (Whitney and Belk 2000).

The site along the south corner of the dam was the only unambiguously identified spawning site. At this site eggs were collected, spawning behavior was observed, and larvae were captured, all of which indicates successful spawning and recruitment at this site. June suckers spawning at this site were likely selecting for substrate size, as indicated above. Visual inspection of other sites of similar depth around the reservoir indicated that this was the only open site with substrates similar to those found in the suckers' original habitat; one other site had similar substrate size but also had inundated riparian vegetation that could interfere with spawning suckers. At the site along the dam, the combination of slight wave action and spawning activity likely provided enough disturbance or flow to reduce fine sediments at this site, increasing interstitial spaces for egg deposition (Bozek et al. 1991). It is unclear why June suckers spawned at the 2 nd site in the cove on the north shore. The substrate where eggs were captured consisted of fine clay and silty substrates, which would not provide the same benefits, particularly protection from predators, of coarser substrates. I was not able to determine if successful recruitment occurred at this site. Future research should examine if June suckers reproduce at this site in successive years (was it an anomaly?), and if so, habitat characteristics should be examined more closely to determine which ones June suckers prefer (e.g., groundwater inputs).

Some suckers may only spawn in streams at night (Scoppettone et al. 1983), so daytime surveys of the stream could have missed suckers spawning at night in Red Butte Creek. However, 
I expected to see suckers congregating near the mouth of Red Butte Creek if such nighttime forays into the stream to spawn were occurring (U.S. Fish and Wildlife Service 1999), but I did not observe such congregating. Furthermore, spawning behavior was observed in the lake during daylight hours; June suckers have been observed spawning during the day in the Provo River as well, indicating that June suckers are not exclusively nocturnal spawners (Shirley 1983). Absence of larvae in or near the mouth of the stream supports the finding that suckers were not spawning in Red Butte Creek.

While failure to find evidence of spawning in Red Butte Creek could be an anomaly of just 1 or 2 years of data (Koch 1973, Scoppettone et al. 2000), it is unlikely that spawning occurred in Red Butte Creek in previous years. Between 1986 and 2002, the water level in Red Butte Reservoir was maintained at a lower level (1631 m elevation) compared to the level maintained during this study (1636 m elevation) because use of the reservoir to supply drinking water was discontinued (Billman 2005). At a water elevation of $1631 \mathrm{~m}$, a substantial waterfall denied access to the stream of not only June suckers but also cutthroat trout (Buelow et al. 2006). The June sucker population growth that occurred during this time period (Billman and Crowl 2007) demonstrated that suckers had successful spawning and recruitment, despite their inability to spawn in Red Butte Creek. This provides evidence that successful spawning within the reservoir occurred in each of the previous years as well as in 2003. Thus, the findings in this study, although limited in years of data collection, are still indicative of spawning in previous years.

The methods used in this study did not provide quantitative data that could be rigorously analyzed, but rather provided qualitative information on the spawning site selection of June suckers in Red Butte Reservoir. Both egg and larval trapping methodology, in particular, provided limited information. The egg collection methodology, however, provided information that would not otherwise have been provided with alternative methods. Given the limited visibility in the reservoir, egg collection methods were the most extensive and appropriate methods for locating spawning sites, particularly if spawning was occurring at depths $>1 \mathrm{~m}$. Larval light trapping provided low numbers of larvae actually collected but did provide presence/absence data for each site. However, spotlighting proved to be a quicker and more successful method for determining presence/absence of larvae. While I did not attempt to collect larvae while spotlighting, doing so would have been easy using a finemesh dip net.

Spawning sites used by June sucker in Red Butte Reservoir indicate that this species is not an obligate stream spawner, but rather a facultative spawner that can also utilize lake habitats for spawning. Similarly, investigations of the spawning habits of other lake suckers have found that these species will spawn in lacustrine habitat. Small numbers of cui-ui sucker have been observed spawning along the shores of Pyramid Lake near the mouths of rivers and possibly near freshwater springs, especially during drought years when low flows prevent access to rivers (Koch 1973, Chatto 1979, Scoppettone et al. 2000). The relatively high salinity of Pyramid Lake restricts successful spawning to these freshwater inputs (Chatto 1979). The contribution of lake spawning to the population is likely low, as fungal growth and predator activity lead to very low survival of the eggs (Chatto 1979). Similarly, adults of the shortnose and Lost River suckers of Upper Klamath Lake have been observed spawning over freshwater springs (National Research Council 2004). The razorback sucker, a riverine species, also demonstrates facultative spawning. In Lake Mohave, a large reservoir on the Colorado River, entrained razorback suckers spawn within the lacustrine habitat with limited success, apparently selecting sites based on substrate size and slight wave action (Bozek et al. 1991). My findings demonstrate that the June sucker is another facultative spawner rather than an obligate stream spawner as originally described. This population of June suckers, however, is unique because it has had such great success in lacustrine spawning, unlike other populations of lake suckers and the razorback sucker, which are largely sustained by stream spawning and stocking efforts.

Despite the success of lake spawning in a refuge population, it is uncertain if lake spawning, when it occurs, significantly contributes or has contributed to the June sucker population in Utah Lake. Under current conditions, recruitment failure, if there are lake-spawning suckers, is likely the result of the same factors 
limiting recruitment of river-spawning suckers, namely lack of rearing habitat and predation by nonnative species (Modde and Muirhead 1994, U.S. Fish and Wildlife Service 1999, Billman and Crowl 2007). Nonnative fish species successfully spawn in Utah Lake (SWCA 2002); thus, it seems plausible that June suckers could spawn there as well if current threats were managed or controlled. Future research should examine June sucker egg survival under conditions in Utah Lake (i.e., on different substrates, at different locations, and in different water-quality conditions) to determine the likelihood of successful recruitment if lake spawning occurred. If successful, future recovery efforts could focus on identifying, monitoring, and restoring potential lake-spawning sites to restore this component of the Utah Lake June sucker population. Additionally, these findings provide criteria that will be important for establishing additional refuge sites for June sucker or a similar species.

\section{ACKNOWLEDGMENTS}

Funding for these studies was provided by the June Sucker Recovery Implementation Program through an account set up with the Central Utah Water Conservancy District. Additional funds were provided by the Ecology Center at Utah State University. The USDA Forest Service provided access to Red Butte Reservoir. Egg traps were provided on loan from J. Ellen Marsden. I thank Dave and Ruth Kikkert for field assistance. Todd Crowl, Mark Belk, Chris Keleher, Josh Rasmussen, and 2 anonymous reviewers provided helpful comments to improve the manuscript.

\section{Literature Cited}

Andersen, M.E., C.J. Keleher, J.E. Rasmussen, E.S Hansen, P.D. Thompson, D.W. Speas, M.D. RoutLEDGE, AND T.N. Hedrick. 2007. Status of June sucker in Utah Lake and refuges. Pages 39-58 in M.J. Brouder and J.A. Scheurer, editors, Status, distribution, and conservation of native freshwater fishes of western North America: a symposium proceedings. Symposium 53, American Fisheries Society, Bethesda, MD.

BELK, M.C. 1998. Age and growth of June sucker (Chasmistes liorus) from otiliths. Great Basin Naturalist 58:390-392.

Belk, M.C., M.J. Whitney, and G.B. Schaalje. 2001. Complex effects of predators: determining the vulnerability of the endangered June sucker to an introduced predator. Animal Conservation 4:251-256.
Billman, E.J. 2005. Population dynamics and foraging ecology of a June sucker (Chasmistes liorus) refuge population. Master's thesis, Utah State University, Logan.

Billman, E.J., AND T.A. Crowl. 2007. Population dynamics of a June sucker refuge population. Transactions of the American Fisheries Society 136:959-965.

Bozek, M.A., L.J. Paulson, and G.R. WiLde. 1991. Spawning season of the razorback sucker, Xyrauchen texanus, in Lake Mohave, Arizona and Nevada. Journal of Freshwater Ecology 6:61-73.

Buelow, K., E.J. Billman, P. Cowely, M. Crawford, T.A. Crowl, C. Keleher, M. Slater, and K. Wilson. 2006. Red Butte Reservoir management plan. Draft of the Utah Department of Natural Resources, Utah Division of Wildlife Resources, U.S. Department of the Interior, U.S. Fish and Wildlife Service, Utah State University, Central Utah Water Conservancy District, U.S. Forest Service, and Bureau of Reclamation to the June Sucker Recovery Implementation Program, Salt Lake City, UT.

Chatto, D.A. 1979. Effects of salinity on hatching success of the cui-ui. Progressive Fish-Culturist 41:82-85

CrisP, D.T. 2000. Trout and salmon: ecology, conservation, and rehabilitation. Blackwell Science, Malden, MA.

Ehleringer, J.R., L.A. Arnow, T. Arnow, I.B. McNulty, AND N.C. Negus. 1992. Red Butte Canyon Research Natural Area: history, flora, geology, climate, and ecology. Great Basin Naturalist 52:95-121.

Floyd, K.B., W.H. Courtenay, and R.D. Hoyt. 1984. A new larval fish light trap: the quatrefoil trap. Progressive Fish-Culturist 46:216-219.

Horns, W.H., J.E. Marsden, and C.C. Krueger. 1989. Inexpensive method for quantitative assessment of lake trout egg deposition. North American Journal of Fisheries Management 9:280-286.

KocH, D.L. 1973. Reproductive characteristics of the cui-ui lakesucker (Chasmistes cujus Cope) and its spawning behavior in Pyramid Lake, Nevada. Transactions of the American Fisheries Society 102:145-149.

Marsden, J.E., C.C. Krueger, and H.M. Hawkins. 1991. An improved trap for passive capture of demersal eggs during spawning: an efficiency comparison with egg nets. North American Journal of Fisheries Management 11:364-368.

Modde, T., AND N. MuirheAD. 1994. Spawning chronology and larval emergence of June sucker (Chasmistes liorus). Great Basin Naturalist 54:366-370.

National Research Council. 2004. Endangered and threatened fishes in the Klamath River Basin: causes of decline and strategies for recovery. National Academies Press, Washington, DC.

ScoppetTone, G.G. 1988. Growth and longevity of the cui-ui and longevity of other catostomids and cyprinids in western North America. Transactions of the American Fisheries Society 117:301-307.

Scoppettone, G.G., P.H. Rissler, and M.E. Buettner. 2000. Reproductive longevity and fecundity associated with nonannual spawning in cui-ui. Transactions of the American Fisheries Society 129:658-669.

Scoppettone, G.G., AND G. VinYaRD. 1991. Life history and management of four endangered lacustrine suckers. Pages 359-378 in W.L. Minckley and J.E. Deacon, editors, Battle against extinction: native fish management in the American West. University of London Press, Tucson, AZ.

Scoppettone, G.G., G.A. Wedemeyer, M. Coleman, and H. BuRgE. 1983. Reproduction by the endangered 
cui-ui in the Lower Truckee River. Transactions of the American Fisheries Society 112:788-793.

SHIRLEY, D.L. 1983. Spawning ecology and larval development of the June sucker. Proceedings of the Bonneville Chapter of the American Fisheries Society 1983:18-36.

Sigler, W.F., AND J.W. Sigler. 1987. Fishes of the Great Basin. University of Nevada Press, Reno.

1996. Fishes of Utah, a natural history. University of Utah Press, Salt Lake City.

SWCA. 2002. Nonnative fish control feasibility study to benefit June sucker in Utah Lake, final report. SWCA, Inc., Environmental Consultants, Salt Lake City, UT.

U.S. Fish and Wildlife Service. 1999. June sucker (Chasmistes liorus) recovery plan. U.S. Fish and Wildlife Service, Denver, CO.
[USOFR] United States Office of the Federal RegISTER. 1986. Endangered and threatened wildlife and plants; final rule determining June sucker (Chasmistes liorus) to be an endangered species with critical habitat. Federal Register 51:61 (31 March 1986):10851-10857.

Whitney, M., And M.C. Belk. 2000. Threatened fishes of the world: Chasmistes liorus Jordan, 1878 (Catostomidae). Environmental Biology of Fishes 57:362.

Received 7 November 2007 Accepted 6 May 2008 